\title{
THE EFFECT OF POSITIVE AND NEGATIVE EVENTS ON CRYPTOCURRENCY PRICES
}

\author{
Olumlu ve Olumsuz Olayların Kripto Para Fiyatları Üzerindeki Etkisi
}

\section{Emrah ÖGET}

\begin{abstract}
Keywords:

Event Study,

Cryptocurrency,

Abnormal Return,

Altcoin.

JEL Codes:

G10, G14, G15, G23.

In recent years, cryptocurrencies have become a new topic for financial studies. In this study, the effects of positive and negative events related to cryptocurrencies on the prices of related cryptocurrencies were researched using the event study. These events include major listing, delisting and airdrop announcements, and SEC enforcements. As a result of the analysis, 22 significant abnormal return values related to negative events and eight significant abnormal return values related to positive events were determined at $1 \%$ significance level within the event window $(-5,+10)$. Therefore, it has been determined that negative events have more effect on cryptocurrencies than positive events. The number of significant cumulative abnormal return values obtained (13 for negative events, three for positive events) also supports these results. The results of the study have crucial implications for investors, centralized cryptocurrency exchanges, and cryptocurrency CEOs. Even after the negative events were announced publicly, pull out of the market will prevent investors from making more losses. In addition, it is recommended that investors sell for profits in case of a rapid high return on the day of the listing announcement. Because it was determined that the prices returned to the equilibrium prices at the closing.
\end{abstract}

$\ddot{\mathbf{O} z}$

Son yıllarda kripto paralar, finansal çalışmalar için yeni bir konu haline gelmiştir. Bu çalışmada kripto paralarla ilgili olumlu ve olumsuz olayların ilgili kripto paraların fiyatları üzerindeki etkileri olay çalışması yöntemi kullanılarak araştırılmıştır. Bu olaylar büyük listeleme ve liste dışı bırakma duyuruları, airdrop duyuruları ve Amerika Birleşik Devletleri Menkul Kıymetler ve Borsa Komisyonu yaptırımlarını içermektedir. Analizler sonucunda $(-5,+10)$ olay penceresi içerisinde $\% 1$ güven seviyesinde olumsuz olaylarla ilgili 22 ve olumlu olaylarla ilgili 8 anlamlı anormal getiri değeri tespit edilmiştir. Dolayısıyla olumsuz olayların kripto paralar üzerinde olumlu olaylardan daha fazla etkisinin bulunduğu ortaya konulmuştur. Elde edilen anlamlı kümülatif anormal getiri değerlerinin sayıları da (olumsuz olaylar için 13, olumlu olaylar için üç) bu sonuçları destekler niteliktedir. Çalışmanın sonuçları yatırımcılar, merkezi kripto para borsaları ve kripto para yöneticileri için önemli çıkarımlara sahiptir. Özelikle kripto paralarla ilgili olumsuz olaylar kamuoyuyla paylaşıldıktan sonra bile piyasadan çıkılması, yatırımcıların daha fazla zarar etmesini engelleyecektir. Ayrıca listeleme duyurularının yapıldığı gün içerisinde anlık yüksek bir getiri oluşması durumunda yatırımcıların kar alması tavsiye edilmektedir. Çünkü kapanışta fiyatların denge fiyatlarına döndüğü tespit edilmiştir.

\footnotetext{
* Dr. Lecturer, Zonguldak Bulent Ecevit University, Devrek Vocational School, emrahoget@beun.edu.tr, ORCID: 0000-0002-7659-4357
}

Makale Geliş Tarihi (Received Date): 18.10.2021 Makale Kabul Tarihi (Accepted Date): 10.02.2022 


\section{Introduction}

Cryptocurrencies are digital and virtual currencies encrypted with blockchain technology as an alternative to fiat money. The first cryptocurrency to be revealed was Bitcoin, and it was introduced in 2009 with an article penned under the pseudonym Satoshi Nakamoto, whose identity is unknown. In this famous article, Nakamoto (2009) proposed a system that allows direct peer-to-peer sending of online payments without going through any financial institution. Therefore, it can be thought that cryptocurrencies are developed against the authority as a decentralized and untraceable technology that is not under the control of governments. There are discussions that Bitcoin enables transactions such as tax evasion, money laundering, and illegal trade to be carried out secretly. Legal regulations, prohibitions, taxation, and blocking policies related to cryptocurrencies are carried out by governments from time to time because the fiat currency is damaged. However, despite all these discussions, Bitcoin continued its development rapidly and exceeded a market value of 1 trillion dollars as of October 9, 2021. With the emergence of Bitcoin in 2009, many different cryptocurrencies broke into the market. Other cryptocurrencies are called Altcoins. According to Coinmarketcap, as of October 2021, there are 7178 different Altcoins in the market and this number is increasing day by day. This information shows the economic importance of the market.

In recent years, cryptocurrencies have become a new topic for financial studies and are studied by researchers in various ways. While researchers focus on whether cryptocurrencies are an investable investment instrument, a speculatively acting bubble, or security, the market, which has grown tremendously during the Covid-19 pandemic, has started to come to the fore more than before in recent years. It is thought that investors turn to cryptocurrencies for various psychological and social reasons such as high inflation, unemployment, desire to get rich, desire for success, fear of missing out on the opportunity. Many emerging centralized and decentralized exchanges experienced significant increases in transaction volumes. Along with these developments, it is seen that the researchers also tested the traditional finance theories that they applied to the stock markets in the cryptocurrency markets. The most striking of these are the studies that test the efficient markets hypothesis exposed by Fama (1970). Therefore, in recent years, studies on the efficiency of the market in the weak form and the efficiency in the semistrong form have been increasing.

This study aims to test the effectiveness of the market in the semi-strong form against the analyzed events by testing the effect of positive and negative events, which investors closely follow, on the prices of related cryptocurrencies. Although the market, whose effectiveness in weak form is still a matter of debate, is not expected to be effective in semi-strong form. It is essential to reveal which of the examined events have more effect on the markets, both in terms of its contribution to the literature and for investors, central stock exchanges, and cryptocurrency CEOs. For this reason, the effects of major listing, delisting, and airdrop announcements and United States Securities and Exchange Commission (SEC) enforcements on cryptocurrency prices, which are thought to be closely followed by investors, are the subject of the study. Binance, the world's largest centralized cryptocurrency exchange by trading volume, offers separate announcement pages for listing, delisting, and airdrop announcements. Therefore, it can be easily deduced that the relevant stock market and investors attach importance to these events. The reason why the announcements made by this exchange are referred to as major announcements is that the Binance exchange is the world's largest cryptocurrency exchange in terms of trading volume. 
A listing announcement is an announcement that a cryptocurrency will begin trading on a centralized exchange. Centralized exchanges make decisions by evaluating the listing applications of cryptocurrency CEOs according to various criteria. While listing criteria for small exchanges involve a few simple procedures, being listed on a major exchange like Binance is considered a great success for the team behind the relevant cryptocurrency. Binance manager Zhao (2021) stated that applications will be kept confidential until the listing announcement is made, otherwise, the agreements between the parties will be violated. In this way, it is tried to prevent information leakage. Delisting refers to the announcement that a previously listed and traded cryptocurrency on the relevant exchange will no longer be traded. Listing on the world's largest stock exchange is seen as a positive announcement for a cryptocurrency, while delisting is considered a negative announcement. Because listing makes positive contributions to a cryptocurrency in terms of recognition, reliability, transaction volume, and so on, while delisting means losing these positive contributions. Therefore, it is expected that the related cryptocurrency will also be affected in parallel with the event. On the other hand, airdrop announcements, mean that a new cryptocurrency is sent to users' wallets for free as a marketing strategy. To benefit from Airdrop campaigns, users are required to meet certain conditions (For example: having $X$ coin in your wallet to take advantage of the $\mathrm{Y}$ coin airdrop). Therefore, it is expected that users who want to benefit from the Airdrop of $Y$ coin will invest in $X$ coin and the price of $X$ coin will be positively affected by this situation. The last group of events, the subject of this research, is about the announcement of enforcement filed against cryptocurrencies by the SEC. The SEC imposes harsh enforcement, alleging that some companies are raising funds through cryptocurrencies. Some cryptocurrency CEOs have settled with the SEC, while others deny the accusations, arguing that they are not securities. However, in both cases, the interested cryptocurrency investors will inevitably make panic sales in the face of negative announcements made by the SEC. Although the negative effect of this enforcement on cryptocurrencies is known for certain, statistically revealing them will provide important information for investors in terms of information leakage and the duration of the negative effect.

The remainder of this study is organized as follows: In Section 2, the first studies on the efficiency of the cryptocurrency market in the literature were mentioned and the results of similar studies were examined. In Section 3, the events whose effects on cryptocurrency prices will be examined are explained and their sources are shown. In chapter 4, the method of the study is mentioned. In the 5th section, the findings obtained from the analyzes were evaluated and in the 6th section, the results and limitations of this study were given and suggestions were made for future studies.

\section{Literature Review}

One of the first studies on the effectiveness of cryptocurrency markets was researched by Urguhart (2016). Urguhart (2016), in a study in which analyzed the price of Bitcoin for the period of 2010-2016, revealed that the price of Bitcoin was not efficient in the weak form for the period examined. However, according to the results of the 2013-2016 sub-period, it was observed that the market became less inefficient. Based on the study of Urguhart (2016), Nadarajah and Chu (2017) applied a simple power transformation (odd integer power of the Bitcoin returns) to the data for the same period and presented evidence that the market is weak-form efficient in all periods, unlike Urguhart (2016). Latif et al. (2017), in a study examining Bitcoin and Litecoin 
using data from the 2015-2016 period, revealed that the market is far from efficient. Bariviera (2017), in a study examining the price of Bitcoin for the period 2011-2017, obtained evidence that market efficiency changes over time. Kurihara and Fukushima (2017), in a study examining the price of Bitcoin for the period 2010-2016, revealed that the Bitcoin market is not efficient, but is getting closer to efficiency. Cheah et al. (2018) found that the Bitcoin market is not efficient and that investors can earn abnormal returns from speculative movements in their study using data for the period 2011-2017. Tiwari et al. (2018) found evidence that the Bitcoin market is generally efficient, with some exceptions, in their study using data for the period 2010-2017. Hawaldar et al. (2019) found evidence that the market is weak-form efficient in their study. They examined Bitcoin and Litecoin using data from 2013-2017. Zargar and Kumar (2019) found that higher frequencies of Bitcoin prices indicate that prices deviate from their random nature, and stated that the market is far from efficient. Apopo and Phiri (2021), in a study using data from five different cryptocurrencies for the years 2009-2019, found evidence of weak-form market efficiency in daily returns but revealed that market efficiency was not valid in weekly returns.

In addition to these studies, there are also studies examining the effectiveness of publicly disclosed information on cryptocurrency prices. Looking at these studies; Shanaev et al. (2018), found a strong and statistically significant negative price response at the attack date in a study examining the effects of 14 individual 51\% attacks against 13 cryptocurrencies. They also found evidence of insider trading in their study. Auer and Claessens (2018) examined the impact of 151 regulatory events on cryptocurrencies carried out by regulatory agencies, central banks, international institutions, and standard-setting bodies between 2015 and 2018 and found that news about regulatory action has a substantial impact on cryptocurrency markets. Jo et al. (2020) examined the effects of 60 positive and negative events about Bitcoin, Ethereum, and Ripple on prices. As a result, even three days before the events, abnormal returns were detected in the exact parallel as the news. In contrast, the highest number of abnormal returns were found on the day of the event. The anomalies continued in the days following the event. In addition, the researchers revealed that negative news has more impact than positive news. Brown and Douglass (2020) examined the effects of 16 major cryptocurrency theft news, which challenged the security and integrity of the cryptocurrency system since 2014, on 10 major cryptocurrencies. Contrary to expectations, they obtained positive anomalies in the days surrounding the events, the reason for which they did not explain. Ante (2020) examined the effects on the transaction volume of 2132 individual Bitcoin transactions involving the transfer of 500 or more Bitcoins between 2018 and 2019 on the Blockchain Network and found that the transaction volume increased even before the transactions were confirmed on the Blockchain network. Therefore, knowledgeable investors follow these transactions and have positions. Mahdy (2021) revealed that negative abnormal returns were obtained in the US stock market on the announcement days of the two halving events in Bitcoin in 2012 and 2016, and therefore the scarce supply of Bitcoin was harmful to the US capital market. Ante (2021) examined the effect of Elon Musk's seven tweets related to Bitcoin and Dogecoin in 2020 and 2021 on the transaction volumes of related cryptocurrencies and revealed that each tweet is associated with abnormal transactions volume. Chokor and Alfieri (2021), in a study examining the effects of 63 regulatory events carried out by public authorities and regulators in 2015-2019, revealed that investors reacted negatively to possible regulations. 


\section{Motivation and Data}

In this study, the announcement of enforcement filed against cryptocurrencies by the SEC, major listing and delisting announcement, and the effect of Airdrop campaigns launched to market a new cryptocurrency on the relevant cryptocurrency prices were investigated. The closing prices of the investigated cryptocurrencies were obtained from the CoinMarketCap website, a widely used cryptocurrency data aggregator in the current literature (i.e Ante, 2020; Brown and Douglass, 2020; Chokor and Alfieri, 2021). In selecting the relevant events, starting with the SEC enforcements, the focus was on other positive and negative events that took place during a period when SEC enforcements were on the agenda. The reason for choosing the event dates as close to each other is to enable different events to be evaluated within similar market conditions. For this reason, the events close to the SEC enforcements were determined and no market value and trading volume comparisons were made in the selection of the cryptocurrency to which the relevant events were linked. Therefore, if different results are obtained against similar events, it can be deduced that differences can be obtained according to the market value and/or transaction volume against the relevant events. The events, event dates and sources used in the study are shown in Table 1. 
Table 1. List of Events

\begin{tabular}{|c|c|c|c|}
\hline Event Type & Event & $\begin{array}{l}\text { Positive/ } \\
\text { Negative }\end{array}$ & $\begin{array}{l}\text { Related } \\
\text { Cryptocurrency }\end{array}$ \\
\hline $\begin{array}{l}\text { SEC } \\
\text { Enforcements }\end{array}$ & $\begin{array}{l}\text { SEC filed a settled cease-and-desist proceeding against } \\
\text { ShipChain, Inc. for conducting an unregistered initial } \\
\text { coin offering of digital tokens, under which ShipChain } \\
\text { agreed to pay a } \$ 2,050,000 \text { penalty, transfer tokens in } \\
\text { ShipChain's possession or control, publish notice of the } \\
\text { order, and request removal of the tokens from digital } \\
\text { asset trading platforms. }(21.12 .2020) \\
\text { SEC filed an action against Ripple Labs, Inc. and two } \\
\text { of its executives, who are also significant security } \\
\text { holders, alleging that they raised over } \$ 1.3 \text { billion } \\
\text { through an unregistered, ongoing digital asset securities } \\
\text { offering. (22.12.2020) } \\
\text { SEC filed a settled cease-and-desist proceeding against } \\
\text { Texas-based blockchain startup company Tierion, Inc. } \\
\text { for conducting an unregistered offering of securities in } \\
\text { the form of a "token sale." Tierion has agreed to return } \\
\text { funds to harmed investors, pay a } \$ 250,000 \text { penalty, and } \\
\text { disable trading in its "tokens." (23.12.2020) }\end{array}$ & Negative & Shipchain (SHIP) \\
\hline \multirow[b]{2}{*}{$\begin{array}{l}\text { Delisting } \\
\text { Announcement }\end{array}$} & $\begin{array}{l}\text { Binance announced that it will list CELO. }(05.01 .2021) \\
\text { Binance announced that it will list the RSK } \\
\text { Infrastructure Framework. (07.01.2021) } \\
\text { Binance announced that it will list RAMP. }(22.03 .2021)\end{array}$ & Positive & $\begin{array}{l}\text { Celo (CELO) } \\
\text { RSK Infrastructure } \\
\text { Framework (RIF) } \\
\text { Ramp (RAMP) } \\
\end{array}$ \\
\hline & $\begin{array}{l}\text { Binance announced that it will delist Tierion on } \\
\text { 12.11.2020. (05.11.2020) } \\
\text { Binance announced that it will delist Aeternity and } \\
\text { HyperCash on 30.12.2020. (25.12.2020) }\end{array}$ & Negative & $\begin{array}{l}\text { Aeternity (AR) } \\
\text { HyperCash (HC) }\end{array}$ \\
\hline $\begin{array}{l}\text { Airdrop } \\
\text { Announcement }\end{array}$ & $\begin{array}{l}\text { Binance has announced that it will support the Spark } \\
\text { (SPARK) Airdrop program for XRP holders. } \\
(25.11 .2020) \\
\text { Binance has announced that it will support the Symbol } \\
\text { (XYM) Airdrop program for NEM (XEM) Holders. } \\
(04.12 .2020) \\
\text { Binance has announced that it will support the Neutrino } \\
\text { Token (NSBT) Airdrop program for Waves (WAVES) } \\
\text { Holders. (05.02.2021) }\end{array}$ & Positive & Waves (WAVES) \\
\hline Note: Events & regarding SEC cyber enforcement actions were & & rom the website \\
\hline
\end{tabular}

\section{Methodology}

The event study method was used in this study. Ethics of research and publication were followed and this study doesn't require any permission from the ethics committee and/or legal or special permission. The event study, which is frequently used in the literature to measure the effect of an event on stock prices, was used to investigate the effect of positive and negative events related to cryptocurrencies on the markets. Benninga (2014: 331-332) stated that the event study consisted of three time periods and summarized these periods in the following timeline; 
Table 2. Event Study Time Line

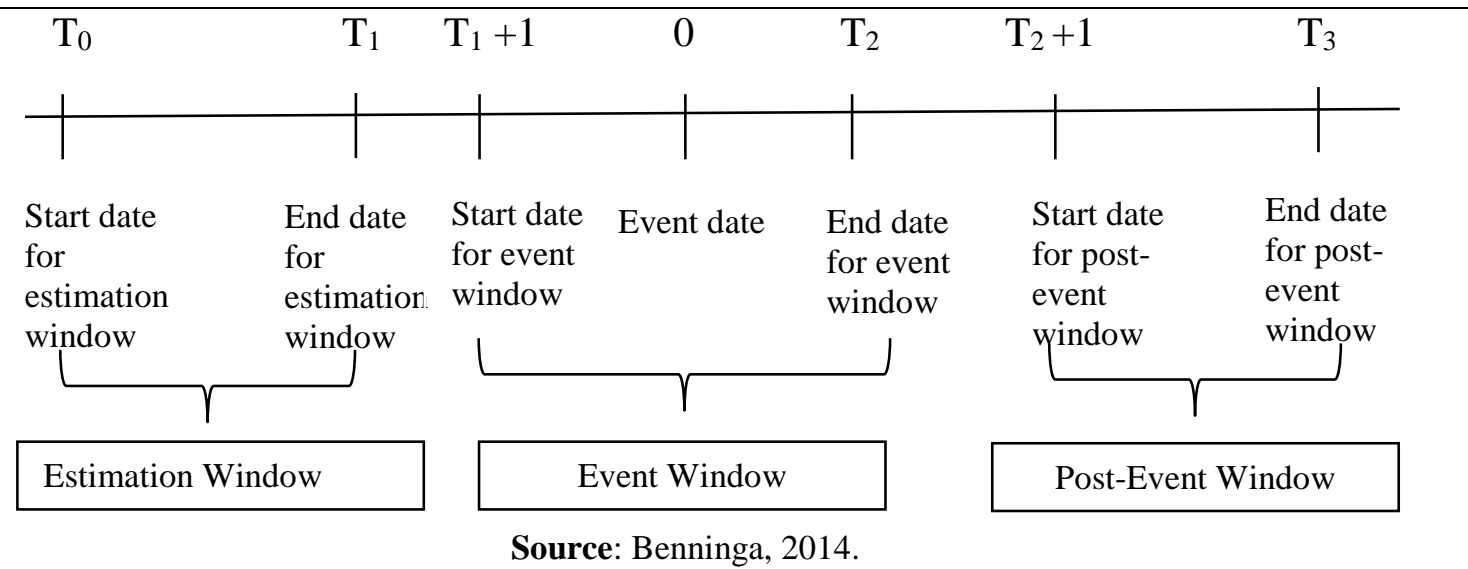

According to Table 2, the $\left(\mathrm{T}_{0}\right)-\left(\mathrm{T}_{1}\right)$ interval represents the length of the estimation window. Time 0 is the day the event occurred. The $\left(T_{1}+1\right)-\left(T_{2}\right)$ interval shows the event window. The $\left(T_{2}+1\right)-\left(T_{3}\right)$ indicates the length of the post-event window. In this study, the estimation window was determined as 120 days and the event window $(-10,+5)$ days. The post-event window was not used. The reason for choosing windows in this way is explained in the following sections.

A model that will allow a comparison of the returns should be used to determine whether the examined events affect the related cryptocurrencies, in other words, whether its cause an abnormal return in cryptocurrencies. Therefore, after determining the events to be investigated and the event dates, the first step is to select a model that will estimate returns. Jo et al. (2020:4797) stated that a reliable proxy to reflect the cryptocurrency market had not been established yet. They used the mean-adjusted returns model to calculate the estimating returns. Shanaev et al. (2018: 10-11) used the constant return model and the market model together, stating that alternative ways of creating a market proxy for cryptocurrencies may be more sensitive to assumptions. They also determined the Bitcoin price as the market proxy for the market model. Ante (2021: 3) used the constant-mean return model in a study, stating that the applicability of more complex asset pricing models for cryptocurrency markets is controversial. Chokor and Alfieri (2021: 164) stated that the CRIX index and the like would be affected by regulatory events related to cryptocurrencies and they preferred the Past Average return when calculating the estimating return to isolate the confounding effects. In this study, considering the discussions in the literature and the decisive role of Bitcoin in the cryptocurrency market, it was deemed appropriate to use the market model. Therefore, Bitcoin closing prices were used as the market proxy. The estimating return on an asset can be expressed using the market model as follows (MacKinlay, 1997: 15):

$$
\mathrm{R}_{\mathrm{it}}=\alpha_{\mathrm{i}}+\beta_{\mathrm{i}}\left(\mathrm{R}_{\mathrm{mt}}\right)+\varepsilon_{\mathrm{i}}
$$

In this equation, the parameters $\alpha_{\mathrm{i}}$ and $\beta_{\mathrm{i}}$ are calculated using the simple least-squares method. $a_{i}$ represents the constant of asset i (returns not related to market returns), $\beta_{i}$ represents the sensitivity of asset $i$ to market returns. $R_{i t}$ is the return of asset $i$ at time $t, R_{m t}$ is the market return, and $\Sigma_{\mathrm{i}}$ is the error term for asset $\mathrm{i}$. Additionally, the error term $\Sigma_{\mathrm{i}}$ is the difference between the return conditional on the event and the expected return unconditional on the event and is a 
direct measure of the abnormal return (Kotari and Warner, 2006: 9). Thus, the abnormal return $\left(\mathrm{AR}_{\mathrm{it}}\right)$ of asset $\mathrm{i}$ on day $\mathrm{t}$ is calculated as follows;

$$
\mathrm{AR}_{\mathrm{it}}=\mathrm{R}_{\mathrm{it}}-\alpha_{\mathrm{i}}-\beta_{\mathrm{i}}\left(\mathrm{R}_{\mathrm{mt}}\right)
$$

Another issue to be decided is how many days the estimation period will cover. In this study, to minimize the risk of confounding effects, it was deemed appropriate to use the estimation period, which is also preferred by Chokor and Alfieri (2021) and covers 120 days before the event window. In addition, Campbell et al. (2003: 441) stated that the shortest estimation period, which is widely accepted in the literature, is 120 days. Another issue to be decided is how many days the event window will cover. Working with daily data, Jo et al. (2020: 4795) use a daily event window $(-6,+6)$ in the work, Brown and Douglass (2020: 6) and Chokor and Alfieri (2021: 164) stated that they work with the daily event window $(-1,+1)$. There is no accepted standard in the literature regarding how many days the event window and the estimation period will cover. In this study, the five days before the event was used to investigate the presence of any leaks of information regarding the events investigated, and the 10 days after the event was used to determine the existence of late reactions to the related events. In addition, event windows (-5, $1),(0,+1),(0,+5)$ and $(0,+10)$ were used to determine on which days the cumulative abnormal returns (CAR) clustered.

Saens and Sandoval (2005: 312) stated that many researchers following Patell (1976) and Dodd and Warner (1983) used a standardized abnormal return (SAR) where its estimation period standard deviation normalizes each abnormal security return. They also stated that this test assumes that individual abnormal returns are cross-sectionally independent and identically distributed.

$\mathrm{H}_{0}: \mathrm{AR}_{\mathrm{it}}=0$ (the abnormal return of asset $\mathrm{i}$ on day $\mathrm{t}$ is equal to zero):

$$
t_{A R_{i t}}=\frac{A R_{i t}}{S D\left(A R_{i}\right)}
$$

The standard deviation $\mathrm{SD}\left(\mathrm{AR}_{\mathrm{i}}\right)$ of each abnormal return for individual assets is calculated as:

$$
S D\left(A R_{i}\right)=\sqrt{\frac{1}{T_{0}-1} \sum_{t=T_{0}}^{T_{1}} A R_{i t}^{2}}
$$

where $T_{1}$ represents the number of days in the estimation period (120 days); $T_{0}$ represents the starting day of the estimation period (-6). Similarly, the t statistics of the cumulative abnormal returns (CAR) of each firm are as follows:

$\mathrm{H}_{0}: \mathrm{CAR}_{\text {iew }}=0$ (the cumulative abnormal return of asset $\mathrm{i}$ within the "ew" event window is equal to zero):

$$
t_{C A R_{i}}=\frac{C A R_{i}}{S D\left(C A R_{i}\right)}
$$

The standard deviation of CARs is found as follows:

$$
S D\left(C A R_{i}\right)=\operatorname{EWSD}\left(A R_{i}\right)
$$


where EW, represents the length of the event window. In addition to these parametric test statistics, non-parametric test statistics are also used in event studies (especially when the data is not normally distributed when working with daily data). However, Brown and Warner (1985: 25) stated that the normal distribution of daily returns did not significantly affect event studies, and the standard parametric tests used in these studies defined the market model well under the null hypothesis. In addition, Dyckman et al. (1984: 26) stated that the standard t-test is an accurate test for measuring abnormal return performance even when the distribution of daily returns is not normal.

\section{Results}

In this study, six negative events related to the effects of SEC's enforcement and major delisting events on cryptocurrencies and six positive events related to major cryptocurrency listing announcements and airdrop campaigns on the relevant cryptocurrency were analyzed using the event study. The EventStudyTools research application developed by Schimmer et al. (2014) was used in the analysis. Table 3 and Table 4 show the AR results for the $(-5,+10)$ event window and the $t$ values for these results, the CAR results for the $(-5,-1),(0,+1),(0,+5)$ and $(0,+10$,$) event$ windows are presented in Table 5. Significance levels are given in the tables according to $10 \%$, $5 \%$, and $1 \%$ levels, and the evaluations regarding the results were made based on the values found to be significant at the $1 \%$ level to make more precise inferences.

Table 3 shows the AR results for negative events. Six significant abnormal returns were detected at the $1 \%$ level regarding delisting announcements. Five of these abnormal returns were negative, and four occurred on the day of the announcement and the days after. A negative abnormal return is observed two days before the event for HC only. Therefore, it can only be mentioned that there is a leak of information regarding this cryptocurrency. While negative abnormal returns were obtained in all cryptocurrencies on the day of the event, positive abnormal returns occurred in TNT two days after the event's announcement. This indicates the buying transactions of the investors in the declining market. However, negative abnormal returns recurred in the following days.

According to Table 3, considering the abnormal return results regarding the announcement of SEC enforcement, it is observed that only abnormal returns related to SHIP were detected in the pre-announcement period. This indicates the existence of the information leak before the SEC enforcement regarding SHIP was announced. On the other hand, the fact that positive and negative abnormal returns were obtained consecutively on the day of the announcement regarding SHIP. This situation, together with gave clues about asymmetric information, some investors were buying in a declining market, while others were selling. Therefore, it is possible to talk about information asymmetry. No significant abnormal returns were detected at the $1 \%$ level before the announcement for XRP and TNT, eight significant abnormal returns were detected on the day and the following days. In addition, seven of these significant returns were negative. It is observed that negative abnormal returns were obtained even on the sixth day after the announcement. When the effects of delisting and SEC enforcement events are compared, it can be said that the impact of SEC enforcement on the related cryptocurrencies is more remarkable and longer-lasting. 
Table 3. AR Results for Negative Events

\begin{tabular}{|c|c|c|c|c|c|c|}
\hline & \multicolumn{3}{|c|}{ AR Results for Delisting Announcements } & \multicolumn{3}{|c|}{ AR Results for SEC Enforcement } \\
\hline & $\begin{array}{c}\text { AE } \\
\text { (t-value) }\end{array}$ & $\begin{array}{c}\text { HC } \\
\text { (t-value) }\end{array}$ & $\begin{array}{c}\text { TNT } \\
\text { (t-value) }\end{array}$ & $\underset{\substack{\text { SHIP } \\
\text { (t-value) }}}{ }$ & $\begin{array}{c}\text { XRP } \\
\text { (t-value) }\end{array}$ & $\begin{array}{c}\text { TNT } \\
\text { (t-value) }\end{array}$ \\
\hline \multirow{2}{*}{-5} & 0.0304 & 0.016 & 0.0241 & $-0.7065 * * *$ & -0.0658 & 0.0196 \\
\hline & $(0.5269)$ & $(0.4571)$ & $(0.3288)$ & $(-3.4197)$ & $(-1.2533)$ & $(0.2295)$ \\
\hline \multirow{2}{*}{-4} & -0.0007 & -0.0064 & -0.0097 & $1.3473 * * *$ & -0.0037 & 0.1211 \\
\hline & $(-0.0121)$ & $(-0.1829)$ & $(-0.1323)$ & $(6.5213)$ & $(-0.0705)$ & $(1.418)$ \\
\hline \multirow{2}{*}{-3} & -0.0723 & -0.0287 & -0.0238 & $0.9384 * * *$ & -0.0453 & $0.1857 * *$ \\
\hline & $(-1.253)$ & $(-0.82)$ & $(-0.3247)$ & $(4.5421)$ & $(-0.8629)$ & $(2.1745)$ \\
\hline \multirow{2}{*}{-2} & $-0.1007 *$ & $-0.2361 * * *$ & -0.0387 & $-0.819 * * *$ & -0.0206 & 0.0169 \\
\hline & $(-1.7452)$ & $(-6.7457)$ & $(-0.528)$ & $(-3.9642)$ & $(-0.3924)$ & $(0.1979)$ \\
\hline \multirow{2}{*}{-1} & -0.0646 & 0.0562 & 0.0315 & -0.0718 & -0.0381 & 0.0918 \\
\hline & $(-1.1196)$ & $(1.6057)$ & $(0.4297)$ & $(-0.3475)$ & $(-0.7257)$ & (1.0749) \\
\hline \multirow{2}{*}{0} & $-0.1024^{*}$ & $-0.0933 * * *$ & $-0.3636 * * *$ & $0.5627 * * *$ & $-0.1916 * * *$ & $-0.1818 * *$ \\
\hline & $(-1.7747)$ & $(-2.6657)$ & $(-4.9604)$ & $(2.7236)$ & $(-3.6495)$ & $(-2.1288)$ \\
\hline \multirow{2}{*}{1} & $-0.1028^{*}$ & $-0.0836 * *$ & -0.108 & $-1.9139 * * *$ & $-0.5226 * * *$ & $-0.2818 * * *$ \\
\hline & $(-1.7816)$ & $(-2.3886)$ & $(-1.4734)$ & $(-9.2638)$ & $(-9.9543)$ & $(-3.2998)$ \\
\hline \multirow{2}{*}{2} & 0.0342 & 0.0303 & $0.5514 * * *$ & -0.2576 & $0.2426 * * *$ & $-0.2749 * * *$ \\
\hline & $(0.5927)$ & $(0.8657)$ & $(7.5225)$ & $(-1.2469)$ & $(4.621)$ & $(-3.219)$ \\
\hline \multirow{2}{*}{3} & -0.028 & -0.0372 & -0.0681 & $0.4212^{* *}$ & $-0.1052 * *$ & $0.1505^{*}$ \\
\hline & $(-0.4853)$ & $(-1.0629)$ & $(-0.9291)$ & $(2.0387)$ & $(-2.0038)$ & $(1.7623)$ \\
\hline \multirow{2}{*}{4} & -0.0418 & -0.0522 & $-0.2226 * * *$ & -0.0372 & $-0.1583 * * *$ & -0.0104 \\
\hline & $(-0.7244)$ & $(-1.4914)$ & $(-3.0368)$ & $(-0.1801)$ & $(-3.0152)$ & $(-0.1218)$ \\
\hline \multirow{2}{*}{5} & -0.0775 & -0.0498 & $0.1547 * *$ & 0.0587 & -0.0326 & $-0.5979 * * *$ \\
\hline & $(-1.3432)$ & $(-1.4229)$ & $(2.1105)$ & $(0.2841)$ & $(-0.621)$ & $(-7.0012)$ \\
\hline \multirow{2}{*}{6} & -0.0494 & 0.0439 & -0.0989 & -0.1197 & $-0.1677 * * *$ & $0.1569 *$ \\
\hline & $(-0.8562)$ & $(1.2543)$ & $(-1.3492)$ & $(-0.5794)$ & $(-3.1943)$ & $(1.8372)$ \\
\hline \multirow{2}{*}{7} & 0.0181 & -0.0291 & $-0.1617 * *$ & $-0.7713 * * *$ & $-0.1269 * *$ & -0.0941 \\
\hline & $(0.3137)$ & $(-0.8314)$ & $(-2.206)$ & $(-3.7333)$ & $(-2.4171)$ & $(-1.1019)$ \\
\hline \multirow{2}{*}{8} & -0.0824 & $-0.1108 * * *$ & -0.0884 & $0.6892 * * *$ & $-0.1045 * *$ & -0.0573 \\
\hline & $(-1.4281)$ & $(-3.1657)$ & $(-1.206)$ & $(3.3359)$ & $(-1.9905)$ & $(-0.671)$ \\
\hline \multirow{2}{*}{9} & 0.0259 & $0.0656^{*}$ & 0.0386 & $-0.3921^{*}$ & 0.0309 & $0.1754 * *$ \\
\hline & $(0.4489)$ & $(1.8743)$ & $(0.5266)$ & $(-1.8979)$ & $(0.5886)$ & $(2.0539)$ \\
\hline \multirow{2}{*}{10} & -0.0745 & 0.018 & -0.0262 & -0.3171 & 0.0623 & 0.0068 \\
\hline & $(-1.2912)$ & $(0.5143)$ & $(-0.3574)$ & $(-1.5348)$ & (1.1867) & $(0.0796)$ \\
\hline
\end{tabular}

Note: $*, 10 \%, * *, 5 \%$, and $* * *$ indicate significance at the $1 \%$ level. 
Table 4 shows the AR results for positive events. Considering the abnormal return results regarding the listing announcements, it is observed that no significant abnormal returns were encountered in the pre-announcement period. On the day of the event, $1 \%$ positive significant abnormal return belonging to CELO was detected only. These findings are insufficient to say that listing announcements have positively impacted the closing prices of related cryptocurrencies, at least in the short term. Considering the abnormal return results regarding the airdrop announcements, it is observed that only three positive abnormal returns were obtained at the $1 \%$ level for the three cryptocurrencies. Therefore, these findings are insufficient to say that the Airdrop announcements cause positive returns on the related cryptocurrency prices.

Table 4. AR Results for Positive Events

\begin{tabular}{|c|c|c|c|c|c|c|}
\hline & \multicolumn{3}{|c|}{ AR Results for Listing Announcements } & \multicolumn{3}{|c|}{ AR Results for Airdrop Announcements } \\
\hline & $\begin{array}{c}\text { CELO } \\
\text { (t-value) }\end{array}$ & $\begin{array}{c}\text { RAMP } \\
\text { (t-value) }\end{array}$ & $\begin{array}{c}\text { RIF } \\
\text { (t-value) }\end{array}$ & $\begin{array}{c}\text { QTUM } \\
\text { (t-value) }\end{array}$ & $\begin{array}{c}\text { XEM } \\
\text { (t-value) }\end{array}$ & $\begin{array}{l}\text { WAVES } \\
\text { (t-value) }\end{array}$ \\
\hline-5 & $\begin{array}{c}-0.0246 \\
(-0.3431)\end{array}$ & $\begin{array}{c}0.059 \\
(0.4319)\end{array}$ & $\begin{array}{c}-0.022 \\
(-0.5882)\end{array}$ & $\begin{array}{l}0.1164 * * \\
(2.1125)\end{array}$ & $\begin{array}{c}-0.0424 \\
(-0.6395)\end{array}$ & $\begin{array}{l}-0.0097 \\
(-0.165)\end{array}$ \\
\hline-4 & $\begin{array}{c}-0.0068 \\
(-0.0948)\end{array}$ & $\begin{array}{c}0.0964 \\
(0.7057)\end{array}$ & $\begin{array}{c}-0.0505 \\
(-1.3503)\end{array}$ & $\begin{array}{c}-0.0303 \\
(-0.5499)\end{array}$ & $\begin{array}{c}-0.0094 \\
(-0.1418)\end{array}$ & $\begin{array}{c}0.061 \\
(1.0374)\end{array}$ \\
\hline-3 & $\begin{array}{c}-0.0327 \\
(-0.4561)\end{array}$ & $\begin{array}{c}0.0768 \\
(0.5622)\end{array}$ & $\begin{array}{l}-0.0716^{*} \\
(-1.9144)\end{array}$ & $\begin{array}{l}-0.0203 \\
(-0.3684)\end{array}$ & $\begin{array}{c}0.0345 \\
(0.5204)\end{array}$ & $\begin{array}{l}-0.0491 \\
(-0.835)\end{array}$ \\
\hline-2 & $\begin{array}{c}0.012 \\
(0.1674)\end{array}$ & $\begin{array}{c}0.0718 \\
(0.5256)\end{array}$ & $\begin{array}{l}0.0926 * \\
(2.4759)\end{array}$ & $\begin{array}{c}0.0504 \\
(0.9147)\end{array}$ & $\begin{array}{c}0.0266 \\
(0.4012)\end{array}$ & $\begin{array}{l}0.0097 \\
(0.165)\end{array}$ \\
\hline-1 & $\begin{array}{c}0.0502 \\
(0.7001)\end{array}$ & $\begin{array}{c}-0.007 \\
(-0.0512)\end{array}$ & $\begin{array}{c}0.0611 \\
(1.6337)\end{array}$ & $\begin{array}{c}0.4322 * * * \\
(7.8439)\end{array}$ & $\begin{array}{c}0.0714 \\
(1.0769)\end{array}$ & $\begin{array}{c}0.0005 \\
(0.0085)\end{array}$ \\
\hline 0 & $\begin{array}{c}0.5401 * * * \\
(7.5328)\end{array}$ & $\begin{array}{c}-0.1335 \\
(-0.9773)\end{array}$ & $\begin{array}{c}0.0803 * * \\
(2.1471)\end{array}$ & $\begin{array}{c}-0.0452 \\
(-0.8203)\end{array}$ & $\begin{array}{l}0.1257^{*} \\
(1.8959)\end{array}$ & $\begin{array}{c}0.1863 * * * \\
(3.1684)\end{array}$ \\
\hline 1 & $\begin{array}{l}-0.1119 \\
(-1.5607)\end{array}$ & $\begin{array}{c}-0.102 \\
(-0.7467)\end{array}$ & $\begin{array}{c}-0.1257 * * * \\
(-3.361)\end{array}$ & $\begin{array}{c}-0.0082 \\
(-0.1488)\end{array}$ & $\begin{array}{c}0.0463 \\
(0.6983)\end{array}$ & $\begin{array}{l}-0.0996^{*} \\
(-1.6939)\end{array}$ \\
\hline 2 & $\begin{array}{c}-0.0459 \\
(-0.6402)\end{array}$ & $\begin{array}{c}0.1763 \\
(1.2906)\end{array}$ & $\begin{array}{c}0.0427 \\
(1.1417)\end{array}$ & $\begin{array}{c}0.0612 \\
(1.1107)\end{array}$ & $\begin{array}{l}-0.0604 \\
(-0.911)\end{array}$ & $\begin{array}{c}-0.0083 \\
(-0.1412)\end{array}$ \\
\hline 3 & $\begin{array}{c}0.0365 \\
(0.5091)\end{array}$ & $\begin{array}{l}-0.1351 \\
(-0.989)\end{array}$ & $\begin{array}{c}-0.0364 \\
(-0.9733)\end{array}$ & $\begin{array}{c}-0.1183 * * \\
(-2.147)\end{array}$ & $\begin{array}{c}-0.0528 \\
(-0.7964)\end{array}$ & $\begin{array}{l}-0.0741 \\
(-1.2602)\end{array}$ \\
\hline 4 & $\begin{array}{c}0.0045 \\
(0.0628)\end{array}$ & $\begin{array}{c}0.0756 \\
(0.5534)\end{array}$ & $\begin{array}{c}-0.0883 * * \\
(-2.361)\end{array}$ & $\begin{array}{c}-0.079 \\
(-1.4338)\end{array}$ & $\begin{array}{c}-0.032 \\
(-0.4827)\end{array}$ & $\begin{array}{c}0.1433 * * \\
(2.4371)\end{array}$ \\
\hline 5 & $\begin{array}{c}-0.046 \\
(-0.6416)\end{array}$ & $\begin{array}{c}0.0133 \\
(0.0974)\end{array}$ & $\begin{array}{l}0.0832 * * \\
(2.2246)\end{array}$ & $\begin{array}{l}-0.0059 \\
(-0.1071)\end{array}$ & $\begin{array}{c}-0.0393 \\
(-0.5928)\end{array}$ & $\begin{array}{c}0.0123 \\
(0.2092)\end{array}$ \\
\hline 6 & $\begin{array}{c}-0.0697 \\
(-0.9721)\end{array}$ & $\begin{array}{c}-0.0255 \\
(-0.1867)\end{array}$ & $\begin{array}{c}0.0284 \\
(0.7594)\end{array}$ & $\begin{array}{c}-0.0093 \\
(-0.1688)\end{array}$ & $\begin{array}{c}0.0058 \\
(0.0875)\end{array}$ & $\begin{array}{c}0.0319 \\
(0.5425)\end{array}$ \\
\hline 7 & $\begin{array}{c}0.0368 \\
(0.5132)\end{array}$ & $\begin{array}{c}0.0257 \\
(0.1881)\end{array}$ & $\begin{array}{c}0.2418 * * * \\
(6.4652)\end{array}$ & $\begin{array}{c}0.0836 \\
(1.5172)\end{array}$ & $\begin{array}{c}-0.0559 \\
(-0.8431)\end{array}$ & $\begin{array}{c}0.0357 \\
(0.6071)\end{array}$ \\
\hline 8 & $\begin{array}{c}0.041 \\
(0.5718)\end{array}$ & $\begin{array}{c}0.0006 \\
(0.0044)\end{array}$ & $\begin{array}{c}-0.1081 * * * \\
(-2.8904)\end{array}$ & $\begin{array}{c}-0.0438 \\
(-0.7949)\end{array}$ & $\begin{array}{c}0.1995 * * * \\
(3.009)\end{array}$ & $\begin{array}{c}0.0517 \\
(0.8793)\end{array}$ \\
\hline 9 & $\begin{array}{c}-0.002 \\
(-0.0279)\end{array}$ & $\begin{array}{c}0.0719 \\
(0.5264)\end{array}$ & $\begin{array}{l}-0.0133 \\
(-0.3556)\end{array}$ & $\begin{array}{c}-0.0793 \\
(-1.4392)\end{array}$ & $\begin{array}{c}-0.0532 \\
(-0.8024)\end{array}$ & $\begin{array}{c}0.0357 \\
(0.6071)\end{array}$ \\
\hline 10 & $\begin{array}{c}-0.0141 \\
(-0.1967)\end{array}$ & $\begin{array}{c}-0.1599 \\
(-1.1706)\end{array}$ & $\begin{array}{c}-0.0526 \\
(-1.4064)\end{array}$ & $\begin{array}{c}0.0428 \\
(0.7768)\end{array}$ & $\begin{array}{c}-0.0312 \\
(-0.4706)\end{array}$ & $\begin{array}{c}-0.0747 \\
(-1.2704)\end{array}$ \\
\hline
\end{tabular}

Note: $*, 10 \%, * *, 5 \%$, and $* * *$ indicate significance at the $1 \%$ level. 
Considering the cumulative abnormal return results shown in Table 5, it is observed that negative cumulative abnormal returns occur at the $1 \%$ significance level for almost all event windows related to negative events. Another noteworthy finding is the emergence of significant negative cumulative abnormal returns for XRP in the pre-event period. Therefore, this situation makes us think that the rumors affect the markets even when there is no official enforcement yet. CAR results support the AR results and the negative impact of SEC enforcements on cryptocurrencies seems significant and long-lasting. When the CAR results of positive announcements regarding cryptocurrencies and Airdrop campaigns are examined, it is observed that very few significant CAR values are obtained, consistent with the AR results. In general, it would be correct to rank the events that most affected the markets as SEC enforcements and delisting announcements. Although there is no definite evidence that the positive events examined affect the markets, negative anomalies could not be obtained. Thus situated a small number of positive anomalies on the dates of positive events shows that the markets tend to react in the same parallel as events.

Table 5. CAR Results

\begin{tabular}{|c|c|c|c|c|c|c|}
\hline \multicolumn{4}{|c|}{ CAR Results for Delisting Announcements } & \multicolumn{3}{|c|}{ CAR Results for SEC Enforcements } \\
\hline & $\begin{array}{c}\text { AE } \\
\text { (t-value) }\end{array}$ & $\begin{array}{c}\text { HC } \\
\text { (t-value) }\end{array}$ & $\begin{array}{c}\text { TNT } \\
\text { (t-value) }\end{array}$ & $\underset{\substack{\text { SHIP } \\
\text { (t-value) }}}{\text { SHI }}$ & $\begin{array}{c}\text { XRP } \\
\text { (t-value) }\end{array}$ & $\begin{array}{c}\text { TNT } \\
\text { (t-value) }\end{array}$ \\
\hline$(-5,-1)$ & $\begin{array}{c}-0.3103 * * \\
(-2.1955)\end{array}$ & $\begin{array}{c}-0.2923 * * * \\
(-3.4095)\end{array}$ & $\begin{array}{c}-0.3802 * * \\
(-2.1175)\end{array}$ & $\begin{array}{l}1.2511^{* * *} \\
(2.4722)\end{array}$ & $\begin{array}{c}-0.3651 * * * \\
(-2.8391)\end{array}$ & $\begin{array}{c}0.2533 \\
(1.2109)\end{array}$ \\
\hline$(0,+1)$ & $\begin{array}{l}-0.2052 * * \\
(-2.5147)\end{array}$ & $\begin{array}{c}-0.1769 * * * \\
(-3.5739)\end{array}$ & $\begin{array}{c}-0.4716 * * * \\
(-4.5494)\end{array}$ & $\begin{array}{c}-1.3512 * * * \\
(-4.6246)\end{array}$ & $\begin{array}{c}-0.7142 * * * \\
(-9.6193)\end{array}$ & $\begin{array}{c}-0.4636 * * * \\
(-3.8386)\end{array}$ \\
\hline$(0,+5)$ & $\begin{array}{c}-0.3183 * * \\
(-2.2521)\end{array}$ & $\begin{array}{c}-0.2858 * * * \\
(-3.3336)\end{array}$ & $\begin{array}{l}-0.0562 \\
(-0.313)\end{array}$ & $\begin{array}{c}-1.1661 * * \\
(-2.3043)\end{array}$ & $\begin{array}{c}-0.7677 * * * \\
(-5.9698)\end{array}$ & $\begin{array}{c}-1.1963 * * * \\
(-5.7188)\end{array}$ \\
\hline$(0,+10)$ & $\begin{array}{c}-0.4806 * * \\
(-2.5114) \\
\end{array}$ & $\begin{array}{c}-0.2982 * * \\
(-2.5689) \\
\end{array}$ & $\begin{array}{c}-0.3928 \\
(-1.6157) \\
\end{array}$ & $\begin{array}{c}-2.0771 * * * \\
(-3.0313)\end{array}$ & $\begin{array}{c}-1.0736 * * * \\
(-6.1658) \\
\end{array}$ & $\begin{array}{c}-1.0086 * * * \\
(-3.5609) \\
\end{array}$ \\
\hline \multicolumn{4}{|c|}{ CAR Results for Listing Announcements } & \multicolumn{3}{|c|}{ CAR Results for Airdrop Announcements } \\
\hline & $\begin{array}{c}\text { CELO } \\
\text { (t-value) }\end{array}$ & $\begin{array}{c}\text { RAMP } \\
\text { (t-value) }\end{array}$ & $\begin{array}{c}\text { RIF } \\
\text { (t-value) }\end{array}$ & $\begin{array}{c}\text { QTUM } \\
\text { (t-value) }\end{array}$ & $\begin{array}{c}\text { XEM } \\
\text { (t-value) }\end{array}$ & $\begin{array}{l}\text { WAVES } \\
\text { (t-value) }\end{array}$ \\
\hline$(-5,-1)$ & $\begin{array}{c}0.5382 * * * \\
(3.0644)\end{array}$ & $\begin{array}{c}0.1635 \\
(0.4886)\end{array}$ & $\begin{array}{c}0.0899 \\
(0.9813)\end{array}$ & $\begin{array}{c}0.5032 * * * \\
(3.7283)\end{array}$ & $\begin{array}{c}0.2064 \\
(1.2709)\end{array}$ & $\begin{array}{c}0.1987 \\
(1.3796)\end{array}$ \\
\hline$(0,+1)$ & $\begin{array}{c}0.4282 * * * \\
(4.2229)\end{array}$ & $\begin{array}{l}-0.2355 \\
(-1.2191)\end{array}$ & $\begin{array}{c}-0.0454 \\
(-0.8584)\end{array}$ & $\begin{array}{c}-0.0534 \\
(-0.6853)\end{array}$ & $\begin{array}{c}0.172 * \\
(1.8344)\end{array}$ & $\begin{array}{c}0.0867 \\
(1.0426)\end{array}$ \\
\hline$(0,+5)$ & $\begin{array}{c}0.3773 * * \\
(2.1483)\end{array}$ & $\begin{array}{l}-0.1054 \\
(-0.315)\end{array}$ & $\begin{array}{c}-0.0442 \\
(-0.4825)\end{array}$ & $\begin{array}{c}-0.1954 \\
(-1.4478)\end{array}$ & $\begin{array}{l}-0.0125 \\
(-0.077)\end{array}$ & $\begin{array}{c}0.1599 \\
(1.1102)\end{array}$ \\
\hline$(0,+10)$ & $\begin{array}{l}0.3693 \\
(1.553)\end{array}$ & $\begin{array}{c}-0.1926 \\
(-0.4251)\end{array}$ & $\begin{array}{c}0.052 \\
(0.4192)\end{array}$ & $\begin{array}{c}-0.2014 \\
(-1.1021)\end{array}$ & $\begin{array}{c}0.0525 \\
(0.2388)\end{array}$ & $\begin{array}{c}0.2402 \\
(1.2317)\end{array}$ \\
\hline
\end{tabular}

Note: $*, 10 \%, * *, 5 \%$, and $* * *$ indicate significance at the $1 \%$ level. 
Charts of CAR values of positive and negative events for $(-5,-1),(0,+1),(0,+5)$ and $(0$, +10 ) event windows are shown in Graph 1 . As can be observed from these graphs, downward curve on the chart has occurred with the realization of negative events. In addition, it is observed that these negative movements continued even on the 10th day after the event. This indicates that the downward trend in returns continues. On the other hand, it is clear that the graphs of positive events don't have as downward curve on the chart as in negative events. Also, even if the events are positive, there is a small percentage of negative CAR values. However, it is striking that CAR values continue to be close to horizontal as move away from the event date.
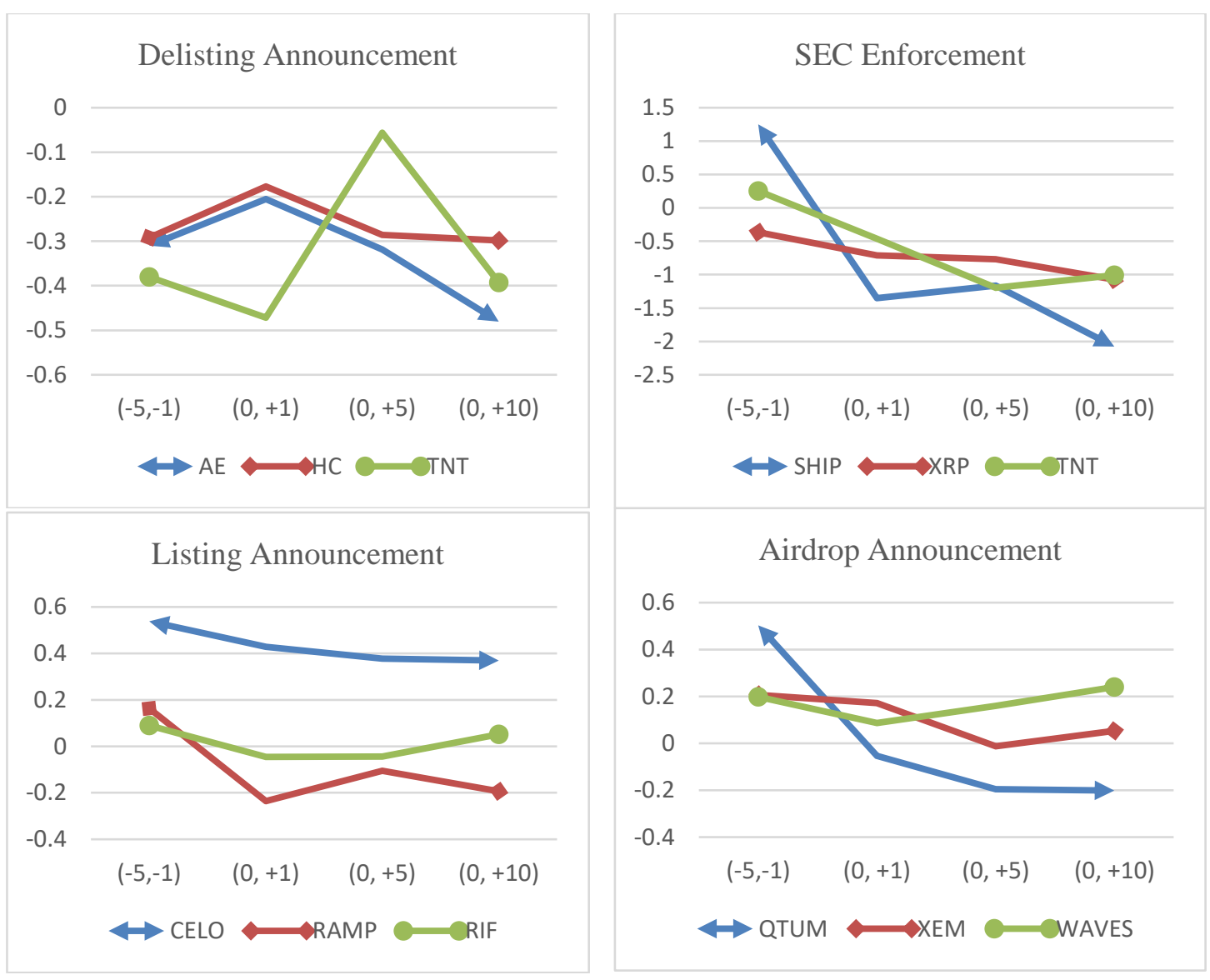

Graph 1. CAR Charts for Possitive and Negative Events

\section{Conclusion}

In this study, the event study analyzed the effect of positive and negative announcements, which are thought to be followed by investors, on the related cryptocurrencies. As a result of the analysis, 22 significant AR values related to negative events and eight significant AR values related to positive events were determined at $1 \%$ significance level within the event window $(-5$, +10 ). It has been determined that negative events have more impact on cryptocurrencies than positive events. The number of significant CAR values obtained (13 for negative events, three for positive events) also supports these results. These results support Shanaev et al. (2018), who found evidence that negative announcements about cryptocurrencies negatively affect cryptocurrencies; Jo et al. (2020), who found evidence that is demonstrating that negative events have more impact 
than positive events; Chokor and Alfieri (2021), who found evidence that markets react negatively to possible public regulation. In addition, it is observed that abnormal returns are partially detected before the events. This suggests that even the emerging rumors affect cryptocurrencies. However, the effect of listing and airdrop announcements on cryptocurrencies is negligible, contrary to popular belief. The abnormal return and cumulative abnormal return results obtained from these positive announcements in the world's largest stock exchange in terms of trading volume prove this situation. The results of this study have crucial implications for investors, centralized exchanges, and cryptocurrency CEOs. Pull out of the market, especially after negative events related to cryptocurrencies are shared with the public, will prevent investors from making greater losses. In addition, it is recommended that investors sell for profits in case of a rapid high return on the day of the listing announcement. Because at the close, the price returned to equilibrium prices.

This study has some limitations. The most important of these limitations is the potential for confounding effects. Therefore, a different event that took place on the same date as the event under investigation may affect the prices of cryptocurrencies and lead to incorrect inferences from the results. Another limitation of this study is the inclusion of a limited number of cases in the study, due to the small number of examples of the cases examined. For future studies, it is recommended to investigate the effects of more events related to cryptocurrencies on the prices of cryptocurrencies with taking into the confounding effects.

\section{Declaration of Research and Publication Ethics}

This study which does not require ethics committee approval and/or legal/specific permission complies with the research and publication ethics.

\section{Researchers' Contribution Rate Statement}

I am a single author of this study. My contribution is $100 \%$.

Declaration of Researcher's Conflict of Interest

There is no potential conflict of interest in this study. 


\section{References}

Ante, L. (2020). Bitcoin transactions, information asymmetry and trading volume. Quantitative Finance and Economics, 4(3), 365-381. doi: 10.3934/QFE.2020017

Ante, L. (2021). How Elon Musk's twitter activity moves cryptocurrency markets (BRL Working Paper Series No. 16). Retrieved from https://papers.ssrn.com/sol3/papers.cfm?abstract_id=3778844

Apopo, N. and Phiri, A. (2021). On the (in)efficiency of cryptocurrencies: Have they taken daily or weekly random walks? Heliyon, 7, 1-10. doi: 10.1016/J.HELIYON.2021.E06685

Auer, R. and Claessens, S. (2018). Regulating cryptocurrencies: assessing market reactions. BIS Quarterly Review, 3, 51-65. Retrieved from https://www.bis.org/

Bariviera, A.F. (2017). The inefficiency of Bitcoin revisited: A dynamic approachi. Economics Letters, 161, 1-4. doi: 10.1016/j.econlet.2017.09.013

Benninga, S. (2014). Financial modeling (4. Ed.). Cambridge, Massachusetts London: The MIT Press.

Binance (n.d.). Listing, delisting and airdrop announcement. Retrieved from https://www.binance.com/en/support/announcement

Brown, J.S. and Warner, B.J. (1985). Using daily stock returns the case of event studies. Journal of Financial Economics, 14, 3-31. doi: 10.1016/0304-405X(85)90042-X

Brown, M.S. and Douglass, B. (2020). An event study of the effects of cryptocurrency thefts on cryptocurrency prices. Paper presented at the Spring Simulation Conference (SpringSim), Fairfax, VA, USA. Retrieved from https://dl.acm.org/doi/10.5555/3408207.3408234

Campbell, K., Gordon, A.L., Loeb, P.M. and Zhou, L. (2003). The economic cost of publicly announced information security breaches: Empirical evidence from the stock market. Journal of Computer Security, 11(3), 431-448. doi: 10.3233/JCS-2003-11308

Cheah, E.T., Mishra, T., Parhi, M. and Zhang, Z. (2018). Long memory interdependency and inefficiency in Bitcoin markets. Economics Letters, 167, 18-25. doi: 10.1016/j.econlet.2018.02.010

Chokor, A. and Alfieri, E. (2021). Long and short-term impacts of regulation in the cryptocurrency market. The Quarterly Review of Economics and Finance, 81, 157-173. doi: 10.1016/j.qref.2021.05.005

CoinMarketCap (n.d.). [Dataset]. Retrieved from https://coinmarketcap.com/coins/

Dyckman, T., Philbrick, D. and Stephan, J. (1984). A comparison of event study methodologies using daily stock returns: A simulation approach. Journal of Accounting Research, 22, 1-30. doi: $10.2307 / 2490855$

Fama, E.F. (1970). Efficient capital markets: A review of theory and empirical work. The Journal of Finance, 25(2), 383-417. doi: 10.2307/2325486

Hawaldar, I.T., Rajesha, T.M. and Souza, L.J.D. (2019). Testing the weak form of efficiency of cryptocurrencies: A case study of Bitcoin and Litecoin. International Journal of Scientific \& Technology Research, 8(9), 2301-2305. Retrieved from https://www.ssrn.com/

Jo, M.H., Nishikawa, Y. and Dandapani, K. (2020). Announcement effects in the cryptocurrency market. Applied Economics, 52(44), 4794-4808. doi: 10.1080/00036846.2020.1745747

Kotari, S.P. and Warner, J.B. (2006). Econometrics of event studies. In B. Espen Eckbo (Ed.), Handbook of corparate finance (pp. 3-36). Amsterdam: North-Holland.

Kurihara, Y. and Fukushima, A. (2017). The market efficiency of Bitcoin: A weekly anomaly perspective. Journal of Applied Finance \& Banking, 7(3), 57-64. Retrieved from https://ideas.repec.org/

Latif, S.R., Mohd, M.A., Amin, M.N.M. and Mohamad, A.I. (2017). Testing the weak form of efficiency market in cryptocurrency. Journal of Engineering and Applied Sciences, 12(9), 2285-2288. doi: 10.3923/jeasci.2017.2285.2288

Mackinlay, A.C. (1997). Event studies in economics and finance. Journal of Economic Literature, 35(1), 13-39. Retrieved from https://www.jstor.org/ 
Mahdy, D.E. (2021). The economic effect of Bitcoin halving events on the U.S. capital market. In N.M. Alsharari (Ed.), Accounting and finance innovations (pp. 1-19). London: IntechOpen.

Nadarajah, S. and Chu, J. (2017). On the inefficiency of Bitcoin. Economics Letters, 150, 6-9. doi: 10.1016/j.econlet.2016.10.033

Nakamoto, S. (2009). Bitcoin: A peer-to-peer electronic cash system. Retrieved from https://bitcoin.org/bitcoin.pdf

Saens, R. and Sandoval, E. (2005). Measuring security price performance using Chilean daily stock returns: The event study method. Cuadernos de Economía, 42(126), 307-328. Retrieved from https://www.jstor.org/

Schimmer, M., Levchenko, A. and Müller, S. (2014). EventStudyTools [Research Apps]. St.Gallen. Retrieved from http://www.eventstudytools.com

SEC (US Securities and Exchange Commission) (n.d.). Cyber enforcement actions. Retrieved from https://www.sec.gov/spotlight/cybersecurity-enforcement-actions

Shanaev, S., Shuraeva, A., Vasenin, M. and Kuznetsov, M. (2018). Cryptocurrency value and 51\% attacks: Evidence from event studies. The Journal of Alternative Investments Winter, 22(3), 65-77. doi: 10.3905/jai.2019.1.081

Tiwari, A.K., Jana, R.K., Das, D. and Roubaud, D. (2018). Informational efficiency of Bitcoin-An extension. Economics Letters, 163, 106-109. doi: 10.1016/j.econlet.2017.12.006

Urquhart, A. (2016). The inefficiency of Bitcoin. Economics Letters, 148, 80-82. doi: 10.1016/j.econlet.2016.09.019

Zargar, F. N. and Kumar, D. (2019). Informational inefficiency of Bitcoin: A study based on high-frequency data. Research in International Business and Finance, 47, 344-353. doi: 10.1016/j.ribaf.2018.08.008

Zhao, C. (2021). How to get your coin listed on Binance.com. Retrieved from https://www.binance.com/en/support/faq/053e4bdc48364343b863d1833618d8ba 